\title{
Los Alamos National Laboratory Simulated Sludge Vitrification Demonstration
}

by

C. A. Cicero

Westinghouse Savannah River Company

Savannah River Site

Aiken, South Carolina 29808

D. F. Bickford

Westinghouse Savannah River Co

SC USA

D. M. Bennert

Clemson University

SC USA

DOE Contract No. DE-AC09-89SR18035

This paper was prepared in connection with work done under the above contract number with the U. S.

Department of Energy. By acceptance of this paper, the publisher and/or recipient acknowledges the U. S.

Government's right to retain a nonexclusive, royalty-free license in and to any copyright covering this paper, along with the right to reproduce and to authorize others to reproduce all or part of the copyrighted paper. 
WSRC-RP-94-00780

Revision 0

\title{
CIEMSON UNIVERSITY DEPARTMENT OE ENVIRONMENTAL SYSTEMS ENGINEERING TECHNICAI TASK PLAN
}

\section{LOS ALAMOS NATIONAL IABORATORY SIMULATED SIUDGE VITRIEICATION DEMONSTRATION

\author{
C.A. Cicero and D.F. Bickford \\ Westinghouse Savannah River Co. \\ D.M. Bennert and T.J. Overcamp \\ clemson University
}




\section{DISCLAIMER}

This report was prepared as an account of work sponsored by an agency of the United States Government. Neither the United States Government nor any agency thereof, nor any of their employees, makes any warranty, express or implied, or assumes any legal liability or responsibility for the accuracy, completeness, or usefulness of any information, apparatus, product, or process disclosed, or represents that its use would not infringe privately owned rights. Reference herein to any specific commercial product, process, or service by trade name, trademark, manufacturer, or otherwise does not necessarily constitute or imply its endorsement, recommendation, or favoring by the United States Government or any agency thereof. The views and opinions of authors expressed herein do not necessarily state or reflect those of the United States Government or any agency thereof.

This report has been reproduced directly from the best available copy.

Available to DOE and DOE contractors from the Office of Scientific and Technical Information, P.O. Box 62, Oak Ridge, TN 37831; prices available from (615) 576-8401.

Available to the public from the National Technical Information Service, U.S. Department of Commerce, 5285 Port Royal Road, Springfield, VA 22161. 


\section{DISCLAIMER}

Portions of this document may be illegible in electronic image products. Images are produced from the best available original document. 


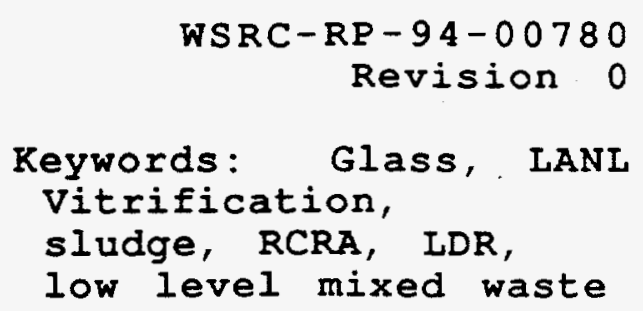

\title{
CLEMSON UNIVERSITY \\ DEPARTMENT OE ENVIRONMENTAI SYSTEMS \\ ENGINEERING \\ TECHNICAI TASK PIAN
}

\section{LOS ALAMOS NATIONAL LABORATORY SIMULATED SLUDGE VITRIFICATION DEMONSTRATION

\begin{abstract}
C.A. Cicero and D.F. Bickford Westinghouse Savannah River Co.

D.M. Bennert and T.J. Overcamp Clemson University
\end{abstract}

Publication Date: $9 / 30 / 94$

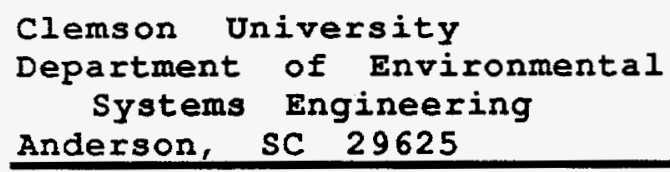

Westinghouse Savannah River Co.

Savannah River Technology Center Aiken, SC 29808 


\section{Westinghouse Savannah River Company}

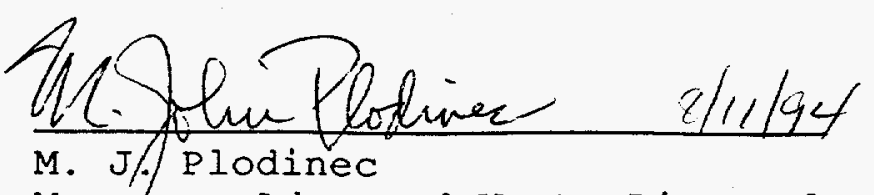

Manąger, Advanced Waste Disposal Technology

Savannah River Technology Center

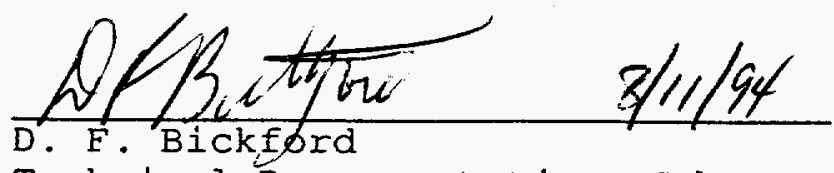

Technical Representative, Advanced waste Disposal Technology Savannah River Technology Center

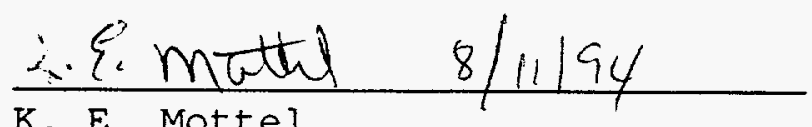

Quality Assurance Coordinator, Waste Compliance Technolgoy Savannah River Technology Center

Department of Environmental systems Engineering

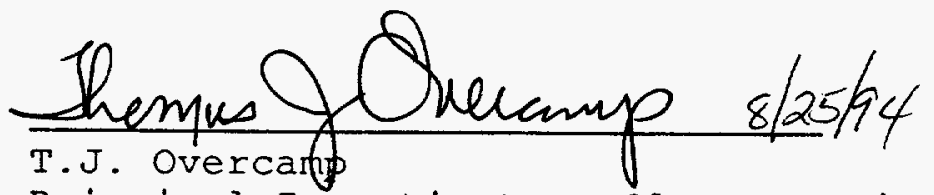

Principal Investigator, Clemson University

Department of Environmental Systems Engineering

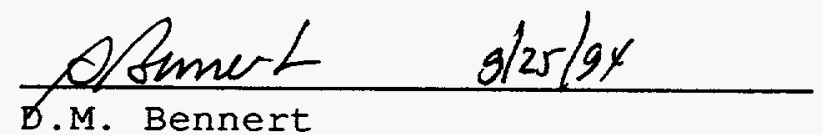

Task Leader, Clemson University

Department of Environmental Systems Engineering 
ACRONYMS

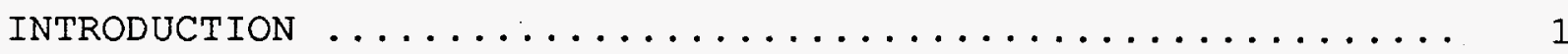

Task Discussion ....................... 1

LANL Sludge Description ................... 2

Facility Description $\ldots \ldots \ldots \ldots \ldots \ldots \ldots \ldots \ldots \ldots \ldots \ldots$

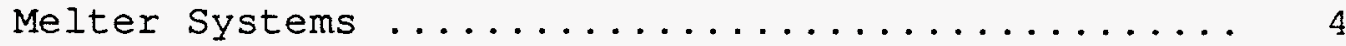

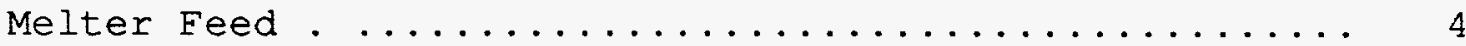

LANL Sludge Simulant ................. 4

Glass Forming Additive ................. 6

Test strategy $\ldots \ldots \ldots \ldots \ldots \ldots \ldots \ldots \ldots \ldots \ldots \ldots \ldots \ldots \ldots \ldots \ldots$

TASK DEFINITION $\ldots \ldots \ldots \ldots \ldots \ldots \ldots \ldots \ldots \ldots \ldots \ldots \ldots \ldots$

Customer Identification ................. 7

Task Objectives ....................... 7

Task Quality Assurance .................... 8

Task Documentation $\ldots \ldots \ldots \ldots \ldots \ldots \ldots \ldots \ldots \ldots \ldots$

Task Responsibilities ..................... 10

Department of Environmental Systems Engineering... 10

Clemson University Task Leader ............. 10

SRTC Technical Representative ............. 11

SRTC Cognizant Quality Function ............. 11

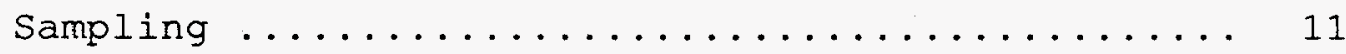

Sample Handling ..................... 11

Analytical Measurements ................ 14

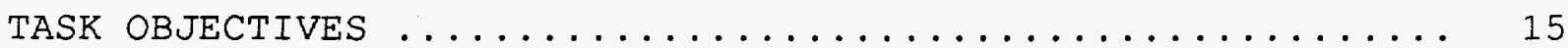


ATTACHMENTS

Attachment A: Run Sample Schedule 


$\begin{array}{ll}\text { AA: } & \text { Atomic Absorption } \\ \text { BDAT: } & \text { Best Demonstrated Available Technology } \\ \text { CU: } & \text { Clemson University } \\ \text { DOE: } & \text { United States Department of Energy } \\ \text { EPA: } & \text { Environmental Protection Agency } \\ \text { GC: } & \text { Gas Chromatograph } \\ \text { GD: } & \text { Glow Discharge } \\ \text { IC: } & \text { Ion Chromatography } \\ \text { ICP : } & \text { Inductively Coupled Plasma } \\ \text { ISE: } & \text { Ion Selective Electrode } \\ \text { LANL: } & \text { Los Alamos National Laboratory } \\ \text { LDR: } & \text { Land Disposal Requirements } \\ \text { MWIP: } & \text { Mixed Waste Integration Program } \\ \text { ORNL: } & \text { Oak Ridge National Laboratory } \\ \text { PCT: } & \text { Product Consistency Test } \\ \text { RCRA: } & \text { Resource Conservation and Recovery Act } \\ \text { SEM: } & \text { Scanning Electron Microscopy/Microscope } \\ & \text { Control } \\ \text { SCUREF: } & \text { South Carolina Universities Research and Education } \\ & \text { Foundation } \\ \text { SRS: } & \text { Savannah River Site } \\ \text { SRTC: } & \text { Savannah River Technology Center } \\ \text { TCLP: } & \text { Toxicity Characteristic Leaching Procedure } \\ \text { TDS: } & \text { Total Dissolved Solids } \\ \text { XRD: } & \text { X-ray Diffraction } \\ \text { XRE: } & \text { X-ray Fluorescence } \\ \text { WSRC: } & \text { Westinghouse Savannah River Company } \\ & \end{array}$




\title{
LOS ALAMOS NATIONAI LABORATORY SIMOLATED SLODGE VITRIFICATION DEMONSTRATION
}

\author{
C.A. Cicero and D.F. Bickford \\ Westinghouse Savannah River Co. \\ Savannah River Technology Center \\ Aiken, SC 29808 \\ D.M. Bennert and T.J. Overcamp \\ Clemson University \\ Department of Environmental Systems Engineering \\ Anderson, SC 29625
}

\section{INTRODOCTION}

\section{TASK DISCUSSION}

Technologies are being developed by the US Department of Energy's (DOE) Nuclear Facility sites to convert hazardous and mixed wastes to a form suitable for permanent disposal. The preferred disposal method would be one that is capable of consistently producing a durable, leach resistant wasteform, while simultaneously minimizing disposal volumes. Vitrification, which has been declared the Best Demonstrated Available Technology (BDAT) for high-level radioactive waste disposal by the EPA ${ }^{1}$, is capable of producing a highly durable wasteform that minimizes disposal volumes through organic destruction, moisture evaporation, and porosity reduction. However, this technology must be demonstrated over a range of waste characteristics, including compositions, chemistries, moistures, and physical characteristics to ensure that it is suitable for hazardous and mixed waste treatment.

The Department of Environmental Systems Engineering at Clemson University (CU) has been selected by the Westinghouse Savannah River Company (WSRC), under SCUREF Task Order \#121, to demonstrate vitrification of simulated wastes that are considered representative of wastes found throughout the DOE complex. These wastes are typically wastewater treatment sludges that are categorized as listed wastes due to the process origin or organic solvent content, and usually contain only small amounts of hazardous constituents. For the most part, the primary constituent of the wastes is flocculation aids, such as $\mathrm{Fe}(\mathrm{OH})_{3}$, and natural filter aids, such as diatomaceous earth and perlite. The filter aids consist mostly of silica, which serves as an excellent glass former; hence, the reason why vitrification is such a viable option.

The DOE's Los Alamos National Laboratory (LANL) is currently operating a liquid waste processing plant which produces an inorganic sludge similar to other waste water treatment streams. Presently, the plant processes 20,000,000 liters of waste per year, which produces two 
hundred and fifty 55 gallon drums of solid residue. The current inventory is approximately $270 \mathrm{~m}^{3}$, with about $139 \mathrm{~m}^{3}$ subject to EPA Land Disposal Requirements (LDR) prohibition. Currently generated material is no longer a mixed waste because source reduction activities have effectively eliminated the Resource conservation and Recovery Act ( $R C R A$ ) regulated constituents.2,3 An alternative wasteform is needed for the sludge due to the limited life of carbon steel drums. Since this waste has characteristics that make it suitable for vitrification and the likelihood of success is high, it was identified as a potential vitrification wasteform by the Mixed Waste Integrated Program (MWIP) and shall be tested at CU.

\section{LANL SLUDGE DESCRIPTION}

In the LANL Liquid Waste Processing Plant, influent water with a total dissolved solids (TDS) content of about $100 \mathrm{ppm}$ is used for decontamination, rinse down, and other activities. This results in a waste water that is $1000 \mathrm{ppm}$ TDS. The resulting waste water is treated with 2000 ppm ferric sulfate, which dissolves, and is later precipitated by adding $8000 \mathrm{ppm}$ of food grade lime (Ca(OH) 2). Precipitate from two sequential stages of precipitation is stored in a tank until it can be filtered. The precipitate is filtered through a rotary drum filter, which is precoated with filter aid. Formerly, diatomaceous earth filter aid was used, but it has been phased out in favor of perlite. 2,3

As filtration continues, the ferric hydroxide precipitate begins to build-up on the filter aid. To remove this build-up, a knife edge slices a thin layer off of the filter aid, which drops by gravity into a 55 gallon carbon steel (painted) drum lined with a polyethylene sheet liner. ${ }^{2}$ Some waste packages may be partially solidified by the addition of portland or gypsum cement. ${ }^{3}$ The resulting waste is homogeneous if it is mixed in 150 gallon batches. However, three phases can occur if it isn't, they are 1) an hydroxide gel which attaches to 2) the filter aid with 3) the pores of both filled with filtrate. The filtrate from this filtration process is monitored, treated with excess $\mathrm{CO}_{2}$ to lower the $\mathrm{pH}$, and discharged directly via the outfall approximately monthly.2

RCRA hazardous organic waste codes that apply to 800 waste drums of the sludge are F001, F002, and F005A, which were caused by low concentrations of miscellaneous hydrocarbon solvents. TCLP results indicated a single occurrence of cadmium exceeding the established Iimits. 2,3

The estimated concentration of bulk constituents in the sludge is given in Table 1. The concentration of the hazardous metals are not well documented and thus are not given. The radioactive element concentrations are reported to be $230-360 \mu \mathrm{g} / \mathrm{g}$ of uranium, $3.3-5.2$ $\mu \mathrm{g} / \mathrm{g}$ of plutonium, and $0.2-0.3 \mu \mathrm{g} / \mathrm{g}$ of americium on a dry weight basis. The $\mathrm{pH}$ of the sludge ranges from 12 - 12.4, indicating that it is saturated with lime, and the total solids is greater than or equal to $30 \mathrm{wt} \%{ }^{3}$ 
TABLE 1 - Estimated LANL Sludge Composition

\begin{tabular}{c} 
constituent \\
\hline $\mathrm{Ca}$ \\
$\mathrm{Si}$ \\
$\mathrm{Fe}$ \\
$\mathrm{Al}$ \\
$\mathrm{Mg}$ \\
$\mathrm{Cl}$ \\
$\mathrm{SO}_{4}^{2-}$ \\
$\mathrm{NO}_{3}^{-}$ \\
$\mathrm{CO}_{3}^{2-}$
\end{tabular}

\begin{tabular}{|c|c|}
\hline Range & (rit 8$)$ \\
\hline 21.2 & -25.9 \\
\hline 7.0 & -13.0 \\
\hline 2.6 & 3.8 \\
\hline 1.2 & 1.4 \\
\hline 0.76 & -0.88 \\
\hline 0.03 & -0.10 \\
\hline 0.05 & -0.22 \\
\hline 0.09 & -2.00 \\
\hline 28.5 & -34.8 \\
\hline
\end{tabular}

Vitrification and subsequent delisting of LANL sludge is advantageous for the following reasons:

- Large volume reductions of the waste can be obtained.

- Glass has been determined to be the BDAT for high level radioactive liquid waste. 1

- Glass has a very high potential for being delisted, due to the toxicity reduction, which would avoid the cost of having to use an expensive RCRA hazardous waste/mixed waste storage vault. Direct disposal to a shallow landfill could be utilized instead.

- Uranium and other hazardous metal releases from glass wasteforms during leach testing are low due to the chemical bonding of metal oxides in the glass structure; thus, their releases would not be much of a concern. 4

- A higher tolerance exists to variations in waste composition with glass formulations.

- High temperature melters permit a wider variation in glass composition, and can result in homogeneous and very durable glasses.

\section{FACILITY DESCRIPTION}

WSRC and the Department of Environmental Systems Engineering at CU have established a 2000 square foot facility as a site dedicated to bench scale and pilot scale vitrification research. This laboratory is equipped with lab bench areas, hooded work areas, and supporting equipment. Melting equipment capable of pilot scale waste vitrification has been supplied by stir-Melter, Inc., and Envitco, Inc. The melting research area consists of a closed building with sufficient power for melter and systems operation, the two melters, complete offgas treatment facilities including quenching, neutralizing, and filtration, and support equipment sufficient to operate the melters and conduct the necessary sampling and testing. 


\section{Melter systems}

The Envitco, Inc., melter is a portable pilot scale vitrification unit and will be used for the simulated LANL sludge vitrification demonstrations. It is a rugged, refractory lined, cold-top melter using four horizontally mounted molybdenum electrodes. The EnVitCo melter is designed to reduce the volatile losses of hazardous compounds. This is achieved by maintaining a layer of low temperature glass and waste (about $200^{\circ} \mathrm{C}$ ) on the top of the high temperature molten glass $\left(1260-1370^{\circ} \mathrm{C}\right)$. As materials move down into higher temperature zones of the melt, the volatile fractions rise and are condensed and trapped in the upper batch. Wastes that have high metal content and high solids fractions may be suitable to the cold top melter vitrification process due to high operating temperatures, lower turbulence, and no moving parts to damage. The cold top melter is theoretically capable of much greater waste volume reductions due to the higher vitrification temperatures. The temperature of the cold top melter can be adjusted to minimize volatility, or to maximize throughput or durability.

\section{MELTER FEED}

\section{LANL Sludge Simulant}

From the limited analyses that were available, a surrogate formulation for LANL sludge was derived by W.D. Bostick of Oak Ridge National Laboratory (ORNL). The nominal elemental concentration of the simulant and the actual sludge based on a dry weight basis are given in Table 2. Cerium was used as the surrogate for uranium and plutonium. 3

\section{TABLE 2 - LANL SLUDGE SIMULANT CONCENTRATION}

\begin{tabular}{c} 
Element \\
\hline $\mathrm{Ca}$ \\
$\mathrm{Si}$ \\
$\mathrm{Fe}$ \\
$\mathrm{Al}$ \\
$\mathrm{Mg}$ \\
$\mathrm{Ce}$
\end{tabular}

Simulant
concentration (o/ka)
240
140
35
14
14
0.85

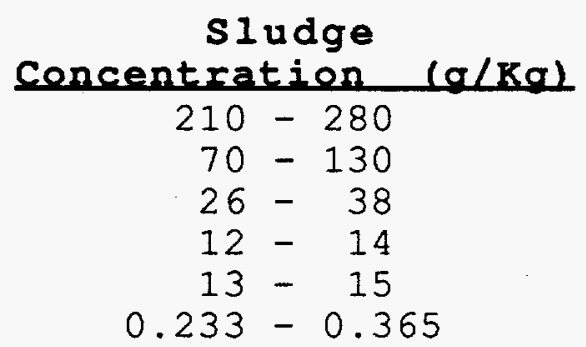

The simulant compounds to be used and the amounts suggested by Bostick are given in Table 3.3 Since no reliable data was found that indicated the concentration of the RCRA metals in the sludge, a spike of $500 \mu \mathrm{g} / \mathrm{g}$ for $\mathrm{Ni}, \mathrm{Cr}, \mathrm{Ba}, \mathrm{Pb}$, and $\mathrm{Cd}$ was suggested. The compounds suggested by Bostick are given in Table 4. He also suggested adding $10 \mathrm{~g} / \mathrm{Kg}$ of naphthalene and/or 1,2-dichlorobenzene so the probable destruction and removal efficiency for RCRA hazardous organic compounds during vitrification could be determined. ${ }^{3}$ 


\section{TABLE 3 - IAANL SLUDGE SIMULANT COMPOSITION}

\begin{tabular}{lc} 
Constituent & Amount $(\mathrm{o} / \mathrm{Kal}$ \\
\hline $\mathrm{CaCO}_{3}$ & 600 \\
$\mathrm{Perlite}\left(\mathrm{SiO}_{2}\right)$ & 300 \\
$\mathrm{Fe}_{2} \mathrm{O}_{3}$ & 50 \\
$\mathrm{Al}_{2} \mathrm{O}_{3}$ & 26 \\
$\mathrm{MgO}$ & 23 \\
$\mathrm{Ce}_{2} \mathrm{O}_{3}$ & 1
\end{tabular}

TABLE 4 - ILANL SLUDGE SIMULANT METALS SPIKE

\begin{tabular}{|c|c|}
\hline compound & Amount $(\sigma)$ \\
\hline$\overline{\mathrm{NiSO}_{4}} \times 6 \mathrm{H}_{2} \mathrm{O}$ & 2.3 \\
\hline $\mathrm{CrCl}_{3} * 6 \mathrm{H}_{2} \mathrm{O}$ & 2.5 \\
\hline $\mathrm{Ba}\left(\mathrm{NO}_{3}\right)_{2}$ & 1.0 \\
\hline $\mathrm{Pb}\left(\mathrm{NO}_{3}\right)_{2}$ & 0.8 \\
\hline $\mathrm{Ce}\left(\mathrm{NO}_{3}\right)_{2} \star 4 \mathrm{H}_{2} \mathrm{O}$ & 1.4 \\
\hline
\end{tabular}

Simulated LANL sludge for the demonstrations at CU will be fabricated using the compounds suggested in Tables 3 and 4 . LANL presently uses Snowflake Hydrated Lime (Food Codex) from Ash Grove Cement Company in Overland Park, Kansas. ${ }^{2}$ The lime used in the simulated sludge development should be obtained from Ash Grove or be of similar composition. Though LANL normally uses perlite from Dicalite Perlite in Torrance, $\mathrm{CA}, 2$ Tech-Flo $2000 \mathrm{X}$ perlite from Renaissance Perlite in Brunswick, Georgia, will be used in the simulated sludge due to its availability. Its composition has been analyzed by C.M. Jantzen of the SRTC 5 and is given in Table 5.

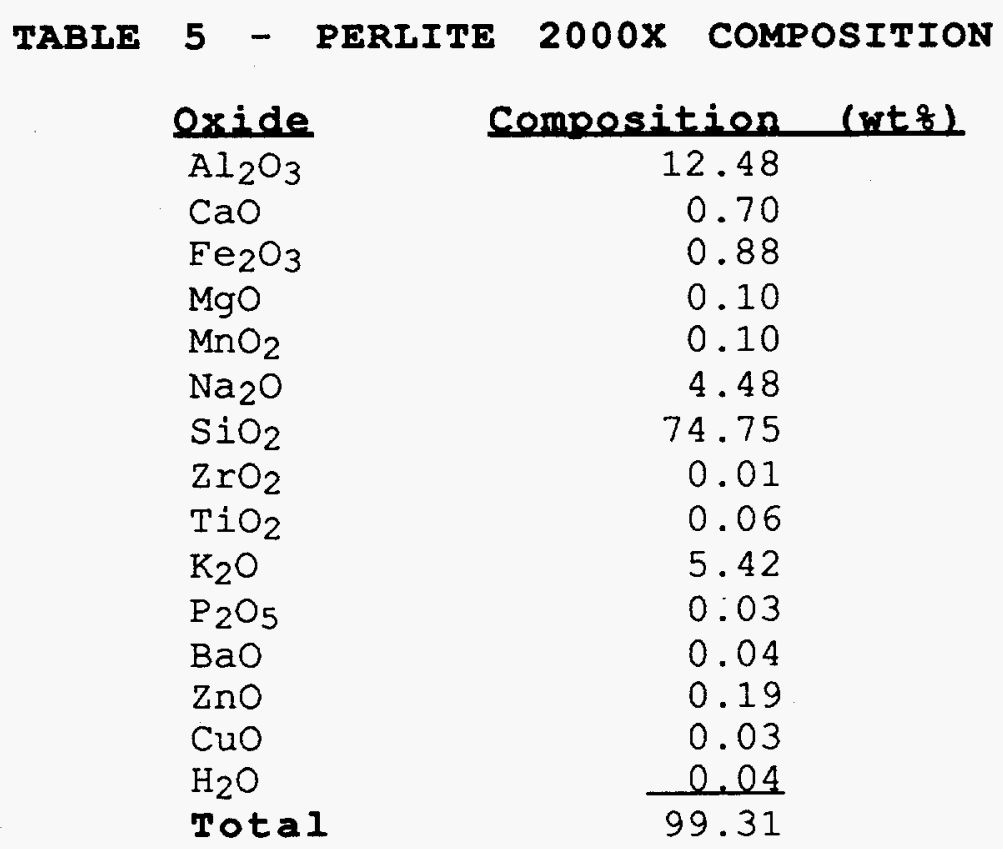




\section{Glass Forming Additive}

For the runs made at $C U$, alumina and silica will be used as the glass forming additives. The amounts to be added were determined in crucible studies performed by Cicero and Andrews at the SRTC. These crucible studies tested various batch compositions in the glass making region of four ternary diagrams. The composition, which was determined to be the most suitable for the Envitco melter by Cicero and Andrews, consisted of 65 wt\% sludge, 10 wt $\%$ alumina, and 25 wt\% silica. 6 Lower melting temperature glass compositions were tested, which would be more suitable for the stirred melter, but none of the fabricated glasses passed both the durabilty tests (TCLP and PCT).

The intent of the glass forming additive additions was to produce a glass which had the lowest releases on the TCLP, while achieving the highest waste loading. For the LANL glasses, $C d$ concentration was the limiting factor for the SRTC crucible studies. It was the only RCRA metal that exceeded the LDR limits on the TCLP, and this occurred with three different glass compositions.

\section{Test strategy}

A melter campaign will be conducted using a mixture of simulated sludge, alumina, and silica in the Envitco melter. The objective of the run will be to test the glass composition to assure that the LDR for listed wastes as required by the RCRA have been met. To determine if the glasses have met this objective, they will subjected to the TCLP. The leachability results will be compared against the TCLP and the LDR limits listed in Table 6. The limits given in Table 6 are per the Code of Federal Regulation (40 CFR 268), revised July 1, 1992.

\section{TABLE 6 - DISPOSAL IIMITS}

$\begin{array}{ccc}\begin{array}{c}\text { RCRA } \\ \text { Regulated } \\ \text { Metal }\end{array} & \begin{array}{c}\text { TCLP } \\ \text { Iimit } \\ (\mathrm{mg} / \mathrm{I})\end{array} & \begin{array}{c}\text { LDR } \\ \text { Iimit } \\ (\mathrm{mg} / \mathrm{I})\end{array} \\ \begin{array}{c}\text { Barium } \\ \text { Cadmium }\end{array} & 100.000 & \mathrm{~N} / \mathrm{A} \\ \text { Chromium } & 1.000 & 0.066 \\ \text { Lead } & 5.000 & 5.200 \\ \text { Nickel } & 5.000 & 0.510 \\ & \mathrm{~N} / \mathrm{A} & 0.320\end{array}$

The main emphases of these campaigns will be to develop a wasteform capable of passing the TCLP and to determine the optimum operating conditions and process limits. The melt rates will be recorded on a mass of feed and glass product per hour basis. When the melters reach steady-state operating conditions, samples will be taken. Steadystate operating conditions occur after the volume of glass produced is greater than the melter tank volume. 


\section{TASR DEFINITION}

\section{CUSTOMER IDENTIFICATION}

The customer for this task is the Advanced Waste Disposal Technology Group of the SRTC. The information obtained during this work will be used to help determine the feasibility of using vitrification as an alternative method of disposal for LANL sludge. Offgas analyses will focus on percentage of melter feed entrained and volatilized as well as percentage nitrate destroyed during vitrification.

\section{TASK OBJECTIVES}

The objective of this task is to characterize the process behavior and glass product formed upon vitrification of simulated LANL sludge. The off-gasses generated from the production runs will also be characterized to help further develop vitrification processes for mixed and low level wastes.

The tasks are individually identified as follows:

1. Vitrify feeds composed of simulated LANL sludge.

2. Determine the material balance for hazardous and tracer compounds around the melter system.

3. Characterize the offgas products of the simulated LANL sludge vitrification process (solids, volatile metals and $\mathrm{NO}_{\mathbf{x}}$ ).

4. Obtain information on power requirements per pound of glass produced.

5. Characterize the secondary streams produced during processing.

6. Perform the TCLP on the simulated sludge and glass product.

7. Perform the PCT on the glass product.

8. Analyze the glass product chemically for cations.

9. Obtain information on melter solids buildup.

10. Obtain electrode and melter corrosion data.

11. Obtain information on the waste volume reduction. 


\section{TASK QUALITY ASSURANCE}

This section details the quality assurance measures and procedures which will be used to control the task.

The Environmental Systems Engineering Quality Assurance Manual ${ }^{7}$, the approved Quality Assurance Task Plan, and the approved Quality Assurance Matrix will be used to provide guidance throughout the performance of the task. Additional guidance will be provided by the SRTC Quality Assurance Department and Kathy Mottel, who is the $Q A$ representative for the waste Compliance Technology Group of the SRTC, as necessary. The general policy of the laboratory will be to emphasize quality activities and prevent quality problems. All personnel assigned to the task will be provided documentation describing the Environmental Systems Engineering QA Manual and will refer to it as necessary. Chemicals and equipment used in performing the task will be of the highest quality. Instrumentation used will have the proper controls and documentation. Research notebooks documenting the progress of the task will be controlled through standard operating procedures. Finally, the Project Quality Assurance Manager will monitor compliance with $Q A$ procedures and guidelines through audits and inspections.

\section{TASK DOCUMENTATION}

The results of the task will be documented in a formal report jointly written by $C U$ and WSRC personnel and, after appropriate technical review, it will be issued as a WSRC report. After release by WSRC and DOE, those portions which do not discuss proprietary equipment or processes may be released to the public per general conditions of the contract. A copy of this report will be included in the records package for the melter campaigns.

For documentation purposes, the melter runs will be identified by a three letter acronym, where the first two letters stand for the site where the sludge came from, and the third letter indicates the run number for that sludge (e.g. LA1).

At the completion of the task, a Records Package will be developed by $\mathrm{CU}$. This package will be sufficiently complete so that the campaigns can be independently reconstructed, if necessary. The Records Package will contain, at least, the following:

(1) A records index, listing all contents of and a number of pages in the records package. Each page of documentation shall be consecutively numbered.

(2) A copy of the requirements document (SCUREF Task Order \#121)

(3) A copy of the SCUREF Technical Task Plan and this document.

(4) The SCUREF Quality Assurance Task Plan and the Quality Assurance Matrix. 
(5) Original documents, or authenticated copies, of procedures actually used during the campaign which would be necessary to reproduce the results of the campaign, including equipment description.

(6) Original documents, or authenticated copies, of operating logs, laboratory notebooks, and other documents used to routinely record the progress of the campaign.

(7) Working copies of procedures (operational and analytical) used in the campaign.

(8) Copies of the outside laboratories' contracts and/or purchase orders, as well as all qualifications of the personnel involved in performing the required analyses. Information on the calibration of equipment and standards used in performing the analyses should be included with all of the results submitted in the records package.

(9) Hard copies of all analytical and process data used in preparing the final summary report.

(10) Copies of summary reports of the results of the campaign.

(11) Copies of computerized data gathered during the operations, including both computer versions and paper copies.

(12) A copy of the qualification records for the CU, WSRC, and other personnel involved in the task.

(13) Copies of SRTC surveillances and associated corrective actions.

(10) At the conclusion of the campaign, two copies of the records package will be transmitted to the SRS for storage. One copy will be provided to the WSRC SCUREF representative as a contract copy. The second copy will be retained by the Advanced waste Disposal Technology Group as a working copy. Both complete copies of the Records Package will be forwarded to the SRTC at the SRS. 


\section{TASK RESPONSIBILITIES}

\section{Department of Environmental systems Engineering}

The Department of Environmental systems Engineering at $C U$ is responsible for:

- understanding and complying with the requirements of the activity as outlined in the Technical Task Plan,

- operating the melter facility in accordance with the proper technical guidance and approved procedures. This includes operation of equipment, logging of essential data, and acquisition of process samples,

- maintaining the general facility and ensuring that all Measurement and Test Equipment (M\&TE) is properly calibrated,

- notifying the SRTC Technical Representative of any conditions that would prevent compliance with the stated requirements, and

- documenting work on a routine basis in a notebook, record book, and/or report.

\section{Clemson University Task Leader}

The responsibilities of the CU Task Leader will be as follows:

- The Task Leader is the operating officer responsible for coordination of the effort and assignment of specific tasks for melter operations to either CU or WSRC employees or their subcontractors. Generally at least one WSRC representative will be permitted access to provide technical oversight and assist operations.

- ensuring that the task is conducted with the appropriate level of control (as defined in the Task QA Plan and the QA Matrix),

- ensuring that all personnel are properly trained and that their qualifications are well documented,

- identifying the customer, the customer's requirements, and the task deliverables,

- ensuring that all documents necessary for the task are prepared and approved,

- providing the opportunity for customer review and approval of any task document, and 
- maintaining activity records in accordance with $Q A$ Procedures.

\section{SRTC Technical Representative}

The SRTC Technical Representative is responsible for:

- approval of this document, including the Task QA Plan section,

- assisting CU in execution of the task plan by providing engineering and technical review,

- assisting $C U$ in providing engineering and technical assistance as it is verbally requested and as it is available, and

- providing or arranging for on-site SRTC representation during periods of operation, as deemed necessary.

\section{SRTC Cognizant Quality Function}

The SRTC Cognizant Quality Function is responsible for:

- approval of the Quality Assurance Task Plan and Quality Assurance Matrix,

- review and surveillance of DESE subcontractors, and

- performing surveillance of DESE.

\section{Sampling}

The Department of Environmental Systems Engineering is responsible for sampling of the system according to the "Run Sample Schedule". This sample schedule will indicate at which location and at what time in the processing a particular sample should be taken. This sampling schedule will also indicate the type of analyses requested and the number of replicates required. The sampling schedule is provided as Attachment $A$. The official sampling schedule will be issued prior to the campaign start and is subject to modification (by mutual consent of the Task Leader and the SRTC Technical Representative) during the course of the campaign.

\section{Sample Handing}

Each process sample will be logged into the "Sample Log Book". An example of how any particular process sample would be logged is shown in Figure 1. The sample will be logged by the sample name and number, the date and time that the sample was taken, the initials of the sampling operator, the analytical code requested, and any comments/observations that the operator and/or researcher might have about the sample. 


\begin{tabular}{|c|c|c|c|c|c|}
\hline SAMP LE NUMBER & $\mid \begin{array}{c}\text { DATE } \\
\text { (MO/DA) }\end{array}$ & $\begin{array}{l}\text { TIME } \\
(24 \mathrm{HR})\end{array}$ & $\begin{array}{l}\text { ANALYTICAL } \\
\text { CODE (S) }\end{array}$ & 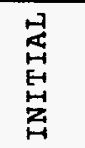 & $\begin{array}{l}\text { COMMENT: description of } \\
\text { sample }\end{array}$ \\
\hline LA1-SLDG-0123 & $9 / 5$ & 0900 & SLUDGE & LAC & $\begin{array}{l}\text { SLUDGE Sample . . repeat } \\
\text { analyses } 3 \text { times. }\end{array}$ \\
\hline LA1-EEED-0124 & $9 / 6$ & 1000 & SLUDGE & MFB & $\begin{array}{l}\text { FEED compositon adjusted, } \\
\text { repeat analyses } 3 \text { times. }\end{array}$ \\
\hline
\end{tabular}

Figure 1. Simulated LANL Sludge vitrification Sample Logging

A sample label with corresponding information, as shown in Figure 2, is placed on each sample bottle and the sample is transported to the proper analytical laboratory for analyses.

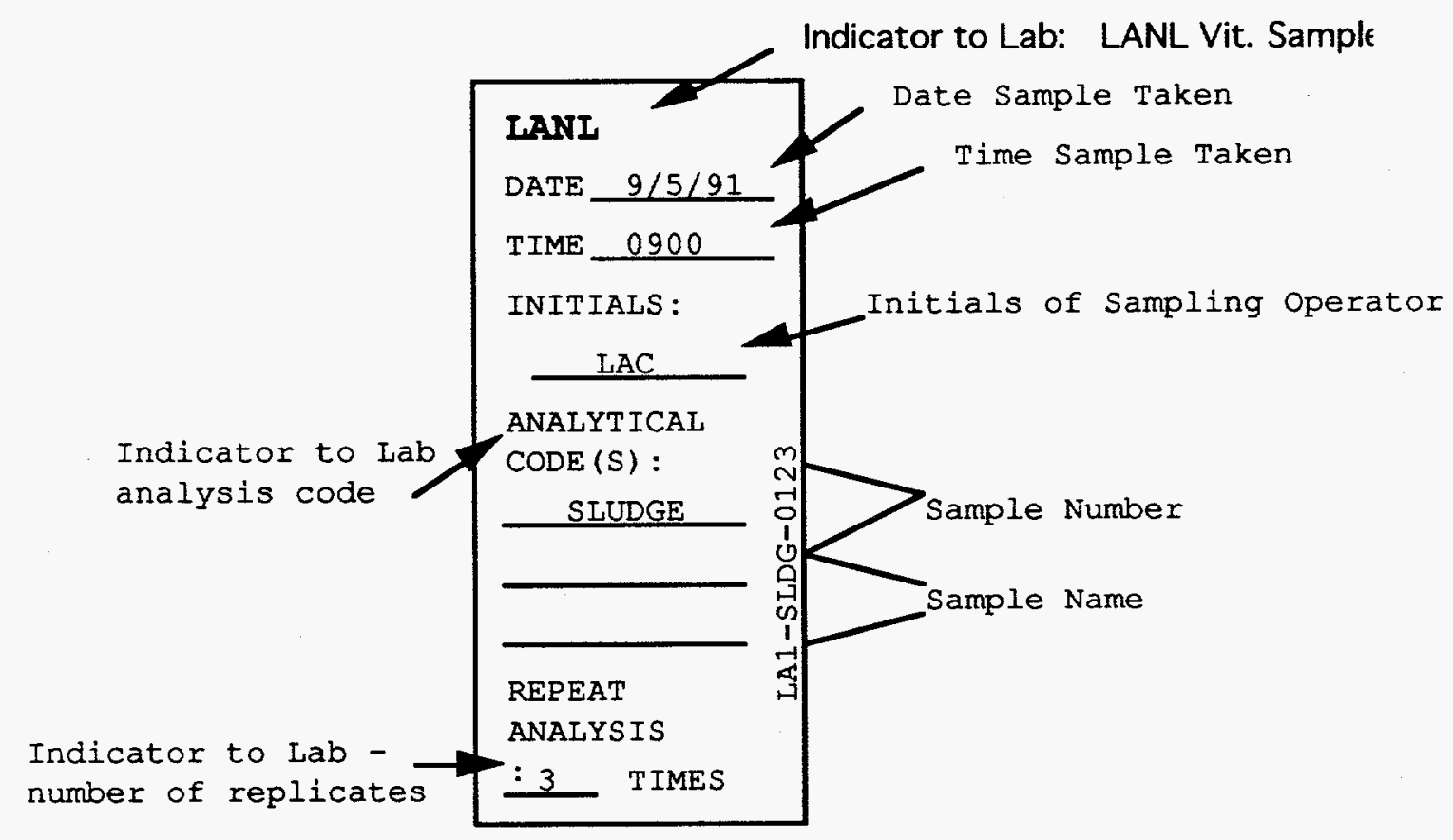

\section{Figure 2. Simulated LANL Sludge Vitrification Sample Labeling}

All samples will be identified by a four-letter acronym and a fourdigit number and will be logged in sequential numerical order. The four-letter acronym will signify when and where the sample was taken during the process operation. The presently defined sample names are listed as follows: 
FEED MATERIALS:

SLDG

FEED

SLUDGE, FEED COMPOSITION NOT ADJUSTED

FEED COMPOSITION, ADJUSTED

MELTER E

GLAS

MELT

OFFG

OGDP

COND

EXHT

\section{OFF-GAS SYSTEM:}

GLASS PRODUCT

MOLTEN GLASS FROM MELT POOL

DIRECT OFFGAS SAMPLE

OFFGAS DEPOSIT

SCRUB SOLUTION/CONDENSATE

OFFGAS AFTER CONDENSATION/SCRUBBING

OTHER :

SPEC

SPECIAL SAMPLES NOT COVERED BY ABOVE NAMES

The analyses required for the samples will be identified by a sixletter acronym. The six-letter acronym will signify what analyses and digestion methods are required. The presently defined analytical codes are listed as follows:

\section{ANALYTICAL CODES}

SLUDGE ICP and AA analyses with an appropriate dissolution, IC and TCLP.

PHSLDG $\quad \mathrm{pH}$ of the sludge material

SPGRAV Specific gravity, g/cc

WTLOSS

WT:SOL

Percent weight loss on heating to $600^{\circ} \mathrm{C}$

ARCHIV Archive sample to be stored until approval of final

The total weight percent solids of the simulated sludge or feed run report.

VOLUME Volume of feed in melter tank

GLASSC ICP and AA analyses with an appropriate dissolution. These determinations are to be performed in triplicate on the glass products and/or melt pool samples from each run.

GLASSD $\mathrm{X}$-ray diffraction on the glass product.

GLASSG

GLASSX

GLASSP

Glow discharge analysis on the glass product.

$X$-ray fluorescence on the glass product.

PCT will be performed on the glass product to determine the durability.

GLASST TCLP will be performed on the glass product to determine the leaching characteristics.

MOLITH

FE2FE3

CASCAD Monolithic samples for subsequent leach testing. The redox ratio of the glass produced

METH5P

OFFNOX

OFFXRD

OGVOST

OGMMST

ORSATG

SEMVOL

Cascade impactor tests

EPA Method 5 particulate analysis.

Offgas analyses for $\mathrm{NO}_{x}$ emissions

$\mathrm{X}$-ray diffraction of the offgas products

EPA volatile organics

off gas multiple metals sample train

ORSAT gas analysis

TNKSOL

Modified EPA Method 5 Semivolatile organics

Tank solids build-up will be analyzed by SRTC. 


\section{Analytical Measurements}

Scoping analyses will be performed by the Department of Environmental Systems Engineering under the guidance of the Environmental systems Engineering Quality Assurance Manual. ${ }^{7}$ Scoping analyses will be used when rapid results are needed for test modifications or when an estimate of results is necessary. For the most part, CU will not perform analyses for "publishable" results; however, if these analyses are performed by $C U, Q A$ guidelines from the Environmental systems Engineering Quality Assurance Manual' and the SCUREF QA Requirements will be followed.

When applicable, SRS analytical methods will be applied.

Written procedures will be used for sample preparations and analyses. In all cases, good laboratory practices, including QA documentation, will be followed during both sample preparation and analysis.

- Appropriate fresh reagents, chemicals, reference standards, and appropriately calibrated gauges, and instruments will be used.

- Standard reference materials or reference standards will be used to calibrate all measuring equipment. These standards will be of checked against traceable to or through unbroken chains to National Institute of Science and Technology (NIST) (or other national reference) Standards.

- Certain laboratory instrumentation, operated by approved users, will be controlled to ensure the quality of the results obtained from these instruments.

When data is needed for "publishable" results, an outside laboratory will be used. The purchase order or contract agreement with this laboratory will be of a level equivalent to or better than the $Q A$ program of $C U$. This laboratory will be required to follow the same $Q A$ guidelines for analytical methods and data reporting as $\mathrm{CU}$. A chain of custody form will accompany all samples submitted to outside laboratories for analyses. This chain of custody form basically identifies the sample and the places it has been and needs to be, along with the analyses required by the laboratory.

The quality of the analytical results will be controlled to ensure that only the most accurate data is reported. To do this, the accuracy and precision of all data will be determined. Control charts and tests on outlying results will be performed, and if it is decided to reject data, the reasons will be well documented. 


\section{TASK OBJECTIVES}

The following section provides a summary of each of the task objectives. In each case, the importance of the objective is summarized and the means by which the objective will be achieved is explained.

\section{Vitrify feeds composed of simulated LANL sludge.}

As stated earlier, campaigns will be performed to prove that simulated LANL sludge can be vitrified to form a durable and leach resistant wasteform. Waste sludge simulant and glass forming additives will be used as the raw materials. The melter campaign will be performed in the Envitco melter.

\section{Determine the material balance for hazardous and tracer compounds around the melter system.}

A material balance will be conducted for compounds (elemental, ionic) in the Melter System. Samples of the waste sludge simulant will be digested and analyzed by ICP, AA, IC, and ISE methods or other suitable methods, in accordance with the sample schedule. In addition, process samples will be taken at various stages in the vitrification processing according to the Run sample schedule (Attachment A). The final glass product samples will also be digested by an appropriate dissolution method and analyzed by ICP and $A A$, or Glow Discharge (GD), and X-ray Fluorescence (XRF) as applicable. The methods used will be in accordance with SRS procedure.

The carbon content of the glass product will also be determined when the organics are used. The samples will be analyzed by digestion and total carbon analyzer, or other acceptable methods for total carbon content. Depending on the analytical equipment used, organic and inorganic fractions may be available.

\section{Characterize the offgas products of the simulated LANL} sludge vitrification process.

The particulate matter from the offgas system will be collected by a capture train in accordance with EPA Method 5 or equivalent. Offgas particulate analysis will be performed using ICP and/or X-ray diffraction and total particulate emissions will be determined.

The semi-volatile organics from the offgas system will be determined by EPA Modified Method 5 (GC/MS) or an equivalent method. Volatile metals within the offgas will be determined by analysis of the scrubber solutions and offgas train deposits. These samples will be analyzed by ICP and/or GC/MS. The main pollutants will be reported, and other volatiles will be checked as necessary. This information will also be used to determine the overall mass balance of the system. 
Source test cascade impactor analysis will be conducted to determine the particle size distribution of the offgas. Attempts will be made to utilize standard sampling head arrangements typical of cascade impactors. In the event that direct, in-stack sampling is not feasible (due to the small diameter offgas pipes), the impactor will be fitted with a sampling nozzle and external heaters, and operated outside of the offgas duct. This will simulate the isothermal conditions of the in-stack sampling, while still operating on an isokinetic sampling basis.

\section{Obtain information on power requirements per pound of glass produced.}

A logbook will be used to record the voltage, current, and resistance while the melters are operating. This information in conjunction with the amount of glass produced will be used to determine the power requirements per pound of glass produced.

\section{Characterize the secondary streams produced during processing.}

When applicable, analyze the condensate tank and exhaust gas for cations and anions. Record volume per unit of feed material, and $\mathrm{pH}$ of condensate. Chain of custody forms will be used for samples submitted to EPA recognized laboratories.

\section{Perform the TCLP on the simulated sludge and glass product.}

TCLP analysis will be conducted on unprocessed simulated sludge for determination of baseline leaching characteristics for characteristic metals as regulated by the EPA. Approximately three analyses will be performed on the simulated sludge. The TCLP will also be performed on the glass product to determine the stability of the product. TCLP RCRA metals and release of $B$ and Si will be monitored. Sodium releases will be monitored when extraction agents that don't contain sodium are used. The performance of the RCRA metals will be compared to the established Land Ban Restrictions and used as criteria for final disposal of the glass. An EPA recognized lab will perform the TCLP analyses to ensure the accuracy of the results. Chain of custody forms will be filled out and retained for TCLP samples.

\section{Perform the PCT on the glass product.}

The Product Consistency Test (PCT) will be performed by SRTC or a certified laboratory on the glass produced. The normalized releases for RCRA materials, $\mathrm{B}, \mathrm{Na}$, and $\mathrm{Si}$ will be reported. This information will be useful for final disposal of the glass.

\section{Analyze the glass products chemically for cations.}

The glass product will be chemically analyzed for cation species. ICP and $A A$ using appropriate dissolution methods will be used analyze for the cations. 
9. Obtain information on melter solids buildup.

At the end of the simulated LANL sludge vitrification campaign, any buildup of material on the cold top melter components will be documented after tearing down the melter and before rebuilding it. Any unusual accumulations or attacked areas will be sampled and submitted to the SRTC Technical Representative for analyses. The SRTC Technical Representative has the option to delay the teardown/rebuild of the melter in the event that further research has been initiated. If no further research is anticipated, the rebuild of the melter will take place in preparation for other programs.

\section{Obtain electrode and melter corrosion data.}

This will be monitored at the same time as the melter solids buildup. The wear and attack on the cold top melter components will be documented before the melter is rebuilt. All corrosion samples will be submitted to the SRTC Technical Representative for analyses. Any signs of electrode or melter corrosion should be documented and reported to SRS.

\section{Obtain information on waste volume reduction.}

Complete records of the amount of simulated sludge and glass forming additive used for each run will be documented. The weight percent solids and specific gravity of the feed for each run will also be recorded. This information will be used to calculate sludge content from liters to dry weight, since waste loading and glass compositions are calculated on a dry weight basis. In addition, melting conditions, such as operating temperature, will also be documented. This information will be used to determine the waste reduction capabilities. Melt rates will be recorded. Large monolithic samples will be obtained, where possible, for future testing. 


$$
\text { WSRC-RP - 94-00780 }
$$

Revision 0

\section{REFTRENCES}

1. Federal Register, "Land Disposal Restrictions for Third Scheduled Wastes, Final Rule," 55 FR 22627 (June 1, 1990).

2. D.F. Bickford, "IANL Waste Composition and surrogate Formulation Summary," MWIP/SR1-3-20-04 (March 1993).

3. W.D. Bostick, D.P. Hoffman, R.J. Stevenson, A. Richmond, and D.F. Bickford, "Surrogate Formulations for Thermal Treatment of LowLevel Mixed Waste: Part IV - waste Water Treatment Sludges," DOE/MWIP-18, Rev. 0.3 (September 29, 1993).

4. G.N. Greaves, N.T. Barrett, G.M. Antonini, F.R. Thornley, B.T.M. Willis, and A. Steel, "Glancing-Angle X-ray Absorption Spectroscopy of Corroded Borosilicate Glass Surfaces Containing Uranium," J. Am. Chem., Soc., 111, 4313-4324 (1989).

5. C.M. Jantzen, Westinghouse Savannah River Company, Laboratory Notebook Number DPSTN-4725.

6. C.A. Cicero and M.K. Andrews, "LANL Simulated Sludge Crucible studies," WSRC-TR-94-0313 (August 29, 1994).

7. Environmental Systems Engineering of Clemson University, Quality Assurance Manual, Version 1.0 ( $\mathrm{JulY} 1,1993$ ) 
WSRC-RP - 94-00780

Revision 0

Attachment $\mathrm{A}$

Run Sample schedule 
Attachment A - Run Sample Schedule, WSRC-RP-94-00780, Revision 0, September 30 , 1994, Page 20 of 21

\begin{tabular}{|c|c|c|c|c|}
\hline Matertal & Description & Analytic Code & \#Samples & \#Replicates * \\
\hline \multirow[t]{7}{*}{ SLDG } & Simulated LANL & SLUDGE & 3 & 1 \\
\hline & sludge & SPGRAV & 3 & 1 \\
\hline & & WTLOSS & 3 & 1 \\
\hline & & WT: $: S O L$ & 3 & 1 \\
\hline & & GLASST & 2 & 3 \\
\hline & & PHSLDG & 3 & 1 \\
\hline & & ARCHIV & 3 & 1 \\
\hline \multirow{7}{*}{ FEED } & & & & \\
\hline & Melter feed & SLUDGE & 3 & $\frac{1}{1}$ \\
\hline & & WTLOSS & 3 & 1 \\
\hline & & WTะSOL & 3 & 1 \\
\hline & & SPGRAV & 3 & 1 \\
\hline & & VOLUME & $5 \star \star$ & 1 \\
\hline & & ARCHIV & 3 & 1 \\
\hline \multirow[t]{7}{*}{ GLAS } & Glass produced & GLASSC & 3 & 1 \\
\hline & & MOLITH & as possible & 3 \\
\hline & & GLASSP & 2 & 3 \\
\hline & & GLASST & 2 & 3 \\
\hline & & ARCHIV & 5 & 1 \\
\hline & & FE2FE3 & 3 & 1 \\
\hline & & GLASSX & 3 & 1 \\
\hline & & & & \\
\hline \multirow[t]{5}{*}{ OFFG } & Direct offgas & METH5P & 2 & 1 \\
\hline & sample (EPA & SEMVOL & 2 & 1 \\
\hline & Methods) & OGMMST & 2 & 1 \\
\hline & & CASCAD & 2 & 1 \\
\hline & & OFFNOX & 2 & 1 \\
\hline & & & & \\
\hline OGDP & Offgas deposit & OFFXRD & 2 & 1 \\
\hline \multirow[t]{2}{*}{ COND } & Scrub solution/ & OGMMST & as possible & 1 \\
\hline & condensate & & & \\
\hline \multirow[t]{3}{*}{ EXHT } & Ooffgas sample & METH5P & 1 & 1 \\
\hline & after scrubbing/ & OGVOST & 1 & 1 \\
\hline & condensation & & & \\
\hline \multirow[t]{4}{*}{ SPEC } & Any special & TNKSOL & as needed & 1. \\
\hline & samples needed & & & \\
\hline & which are not & & & \\
\hline & covered above & & & \\
\hline & & & & \\
\hline \multicolumn{5}{|c|}{ *The number of replicates refers to the number of times that an analyses is to } \\
\hline \multicolumn{5}{|c|}{ be performed. For example, a sludge material will be sampled three different } \\
\hline \multicolumn{5}{|c|}{\begin{tabular}{|l|l|l|} 
times and separately digested and analyzed. & & \\
\end{tabular}} \\
\hline \multirow{2}{*}{\multicolumn{5}{|c|}{$* \star$ An initial volume measurement is to be taken, as well as four other volume }} \\
\hline \multicolumn{4}{|c|}{ measurements during melting. The time that these samples are taken should } & \\
\hline be recordes & so that the melt $r$ & e with time car & de determined & \\
\hline
\end{tabular}


Distribution:

WSRC: E.W. Holtzscheiter, 773-A

E.F. Duhn, 773-A

M.J. Plodinec, 773-A

J.R. Harbour, 773-43A

D.A. Crowley, 704-T

L.F. Landon, 704-T

C.T. Randal1, 704-T

D.F. Bickford, 773-A

C.A. Cicero, 773-41A

K.E. Mottel, 773-43A

J.V. Stewart, 770-A

S.R. Loflin, 773-42A

M.K. Andrews, 773-A

G.S. Bumgarner, 773-41A

B.D. Helton, 773-41A

D.T. Herman, 773-41A

K.J. Imrich, 773-A

C.J. Jantzen, 773-A

A.L. Kielpinski, 773-41A

J.C. Marra, 773-A

A. Applewhite-Ramsey, 704-35S

W.G. Ramsey, 773-A

R.F. Schumacher, 773-41A

J.C. Whitehouse, 786-6A

Glass Technology Group (10)

TIM, 7.03-43A (4)

CU: D.M. Bennert, DESE

T.J. Overcamp, DESE

J.L. Resce, DESE

ORNL: J.B. Berry

W.D. Bostick

LANL: R. Nakaoka, MS E517

other distribution to be provided by westinghouse Savannah River Company 